\title{
КОНСУЛЬТАЦИИ
}

\section{SELF-ORGANISING SYSTEMS IN THE CONTEXT OF ACADEMIC ENVIRONMENT}

\author{
T. V. Kuprina ${ }^{1}$, A. P. Beketova ${ }^{2}$ \\ Ural Federal University named after the first President of Russia B. N. Yeltsin, \\ Ekaterinburg, Russia. \\ E-mail: 1tvkuprina@mail.ru; ${ }^{2 a n n i s h u a r a @ y a . r u ~}$
}

\section{S. M. Minasyan}

Armenian State Pedagogical University after Kh. Abovyan, Yerevan, Armenia. E-mail: s.minasyanpmesi@gmail.com

Abstract. Introduction. In the era of globalisation, which affects all spheres of modern social life (political, financial, scientific, technical, religious, cultural), the processes of internationalisation and academic migration in higher education have significantly intensified. The rapidly growing mobility in higher education, when students study outside their country of residence, is accompanied by certain problems, which include students' adaptation to the conditions of unfamiliar urban environment. The introduction of new methodological tools for teaching humanitarian disciplines in universities can contribute to the elimination of barriers and successful transition of students to another, different from their customary, socio-cultural environment.

The aim of the research was to present the results of experimental work aimed at the development of students' intercultural communicative tolerance within the foreign language learning, and to reveal the role of self-organising systems in the university international academic environment.

Methodology and research methods. The study is based on the theory of self-organising systems. In the process of designing and application of the authors' technology aimed at developing students' intercultural communicative tolerance, experimental methods and the method of comparative analysis were used.

Results and scientific novelty. It has been shown that academic migration is a self-organising system characterised by socio-cultural instability. The factors of human transition from one urboecological niche to another, which often disturbs the balance of social systems, have been described. Lacking knowledge about such processes in the theory and practice of pedagogy within higher education has been stated. Insufficient level of intercultural communicative tolerance of Russian (132 people) and foreign (40 people) students, who studied at the Ural 
Federal University (Ekaterinburg, Russia) in 2015, has proved the necessity of its systematic focused formation. The technology for the development of this type of tolerance within the framework of the 'Foreign Language' discipline has been proposed. The approbation of the technology has demonstrated its effectiveness. The students have not only acquired the necessary competencies, but also learned to adapt to the new academic environment, as well as had the opportunity to directly participate in the creation of their own academic programs.

Practical significance. The research confirms the productivity of mutual adaptation of students to an unfamiliar socio-cultural academic environment. The author's technology of intercultural communicative tolerance development can be used to optimise the pedagogical conditions of maintaining the processes of internationalisation and academic mobility within universities.

Keywords: academic migration, self-organising systems, intercultural communicative tolerance.

Acknowledgments. The article was prepared with the financial support of the Russian Foundation for Basic Reserach № 16-02-00164 "Scientific and Methodological Tools for Measuring, Assessing and Managing the Factors of Social and Economic Inequality in the System of Reproduction of the Labour Potential in Russian Regions".

For citation: Kuprina T. V., Beketova A. P., Minasyan S. M. Self-organising systems in the context of academic environment. The Education and Science Journal. 2019; 1 (21): 150-169. DOI: 10.17853/1994-5639-2019-1-150-169

\title{
САМООРГАНИЗУЮЩИЕСЯ СИСТЕМЫ В КОНТЕКСТЕ АКАДЕМИЧЕСКОЙ СРЕДЫ
}

\author{
Т. В. Куприна ${ }^{1}$, А. П. Бекетова ${ }^{2}$ \\ Уральский федеральный университет им. первого Президента России \\ Б. Н. Ельиина, Екатеринбург, Россия. \\ E-mail:1tvkuprina@mail.ru; 2annishuara@ya.ru
}

\section{С. М. Минасян}

Армянский государственный педагогический университет им. Х. Абовяна, Ереван, Армения. E-mail: s.minasyanpmesi@gmail.com

Аннотаиия. Введение. В эпоху гцобализации, затрагивающей все сферы жизнедеятельности в современном обществе: политическую, финансовую, научно-техническую, религиозную, культурную, в высшей школе заметно активизировались процессы интернационализации и академической миграции.

Образование и наука. Том 21, № 1. 2019/The Education and Science Journal. Vol. 21, № 1. 2019 
Быстрые темпы роста мобильности высшего образования, когда студенты осваивают программы профессиональной подготовки за пределами страны, гражданами которой они являются, сопровождаются опредеменными проблемами, в том числе связанными с адаптацией обучающихся к условиям мало знакомой урбоэкологической среды. Устранению барьеров для успешного перехода студентов в иное, отмичающееся от привычного социокультурное пространство может способствовать внедрение в вузовскую практику нового методического инструментария преподавания гуманитарных дисциплин.

Цели публикации - представить результаты экспериментальной работы, направленной на развитие межкультурной коммуникативной толерантности студентов на занятиях по иностранному языку, и раскрыть роль самоорганизующихся систем в университетской международной образовательной среде.

Методология иметодики. Исследование осуществлялось с опорой на ключевые положения теории самоорганизующихся систем. При создании и апробации авторской технологии иноязычного обучения применялись опытно-экспериментальные методы и метод сравнительного анализа.

Результаты и научная новизна. Показано, что академическая миграция является самоорганизующейся системой, характеризующейся социокультурной нестабильностью. Описаны факторы перемещения человека из одной урбоэкологической ниши в другую, которое нередко нарушает равновесие социальных систем. Констатируется малый объем информации о данных процессах в теории и практике педагогики высшей школы. Установленный в ходе мониторинга недостаточный уровень межкультурной коммуникативной томерантности у российских (132 человека) и иностранных (40 человек) студентов, обучающихся в Уральском федеральном университете (г. Екатеринбург, Россия) в 2015 году, убеждает в необходимости ее планомерного целенаправменного формирования. Предможена технология поступательного развития этого вида толерантности в рамках курса иностранного языка в вузе. Апробация технологии продемонстрировала ее эффективность. Студенты не только приобрели требующиеся компетенции, но и научились самостоятельно приспосабливаться к новой академической обстановке, а также получили возможность непосредственно участвовать в разработке собственных индивидуальных программ обучения.

Практическая значимость. Проведенное исследование подтверждает продуктивность взаимоадаптации студентов, попадающих в незнакомое социокультурное образовательное пространство. Авторская технология развития межкультурной коммуникативной толерантности может использоваться дмя оптимизации педагогических условий сопровождения процессов интернационализации университетов и академической мобильности.

ключевые слова: академическая миграция, самоорганизующиеся системы, межкультурная коммуникативная толерантность. 
Благодарности. Статья подготовлена при финансовой поддержке РФФИ № 16-02-00164 «Научно-методические инструментарии измерения, оценки и управления факторами социально-экономического неравенства в системе воспроизводства трудового потенциала регионов России".

Для иитирования: Куприна Т. В., Бекетова А. П., Минасян С. М. Самоорганизующиеся системы в контексте академической среды // Образование и наука. 2019. T. 21, № 1. С. 150-169. DOI: 10.17853/1994-5639-2019-1$150-169$

\section{Introduction}

In the modern world, environmental terminology is increasingly used to describe social systems, social groups and their interactions. The concept of the interaction of representatives of different cultures in the context of globalisation on the basis of symbiosis (the interaction of two organisms living in the same environment) and antibiosis (antagonistic relations that limit the possibilities of one of the interacting organisms) is offered by Tamar Mebuke (2016), noting that the old relations are destroyed, and new is very difficult to create due to historical, cultural and linguistic differences. Next, the author asks questions, how to live in a new global world and not to lose our identity? How to make the process of globalisation mutually beneficial and achieve the goal of cultural symbiosis, enriching all peoples? [1]

Some answers may be found in modern Urboecology studying the features of the ecological space of the city and urbanisation also considers the influence of anthropogenic factors on the development of the urban space. So, it is closely connected with Anthropoecology (Human Ecology) considering not only the traditional views on ecology of human and society relations with nature but also the relations between the structural units of the society. The object of research in Anthropoecology is social processes in relation to the state of the subject (person, group of people, including intercultural community) which appear in different areas of life.

So, in today's Urboecology one must take into account the demographic and migratory factors including academic migration as well, the number of which increases with each year.

Research of educational migration shows that every year there is an increasing competition between countries for academic migrants as foreign students are both a norm of international cooperation and 'soft power' in the context of the geo-cultural space, and future 'quality labor migrants' (young, embedded in the socio-cultural context). The increasing share of academic 
migration in the total migration flow provides greater manageability of the immigration process; therefore, the academic migration can be considered an important component in the security concept of any country [2, p. 188-190].

It should be noted that up to now there is no exact definition of academic mobility comparing with academic migration. Thus, chapter 14 "International Cooperation in Field of Education" of the federal law "On Education in the Russian Federation" stipulates that "the Russian Federation promotes the development of cooperation between Russian and foreign educational organisations, international academic mobility of students, pedagogical, scientific and other employees of the educational system"1.

On the other hand, in the "Concept of State Migration Policy of Russian Federation for Period up to 2025" the following definition of academic mobility is given: "Academic mobility is the international movement of scientists and teachers in order to carry out scientific and teaching activities, exchange experiences, present research results and other professional purposes" 2 . There may be some contradiction: the definition does not take into account students but the text of this Concept indicates an increase in foreign students in Russian educational institutions and improvement of conditions for their study there.

So, from our point of view, academic mobility can be considered as part of migration processes with different content and characteristics. In the modern context, it is increasingly often referred to the academic migration of students.

On the other hand, host countries should also adapt to constantly changing inner conditions of the urboecological space. The high degree of academic migration requires a well-developed infrastructure (hostels, health insurance, etc.), availability of financing sources (scholarships, travel grants, etc.), high language skills of students and lecturers enable to teach and study abroad as well as the psychological readiness of educational migrants to adapt to the new conditions.

The third forum on migration, organised by the European Economic and Social Committee together with the European Commission in Brussels,

1 Об образовании в Российской Федерации. Федеральный закон РФ от 29 декабря 2012 г. № 273-ФЗ. Ob obrazovanii v Rossiyskoy Federatsii: feder. zakon Ros. Federatsii ot 29 dekabrya 2012 g. № 273-FZ = On Education in the Russian Federation: Federal Law. Ros. Federation, 29 December, 2012, № 273-FZ. Available from: fzakon.ru/273-Ф3 (In Russ.)

2 Kontseptsiya gosudarstvennoy migratsionnoy politiki Rossiyskoy Federatsii na period do 2025 goda $=$ Concept of State Migration Policy of Russian Federation for Period up to 2025. Available from: http://www.consultant.ru/document/cons_doc_ LAW_131046/ (In Russ.)

Образование и наука. Том 21, № 1. 2019/The Education and Science Journal. Vol. 21, № 1. 2019 
has noted that integration is a key factor. It is extremely important to justify the expectations of both migrants and the host society. The Belgian city of Mechelen, home to 128 nationalities, can serve as a successful example of integration and cultural diversity. Bart Somers, Mayor of Mechelen, who received the World Mayor Prize 2016 in recognition of his outstanding achievements in organising life and long-term integration of migrants from different cultures, religions and social origins, notes that the most important is the restoration of common values and the recognition that free societies change with time [3].

Consequently, practical activities should be aimed at optimising the interactions between all the actors involved: analysis of interacting social structures in different socio-cultural contexts, their adequate assessment and work with different gender, ethnic, age and other groups under urboecological space.

Thus, it is necessary to study the human factor, constantly moving from one ecological niche to another (housing, work and study places, transportation, recreation, etc.). Moreover, with increasing urbanisation and space alienation processes people must have the complex adaptive mechanisms (physiological, psychological, social) that are not limitless but can be developed and improved.

\section{Literature Review}

In the context of the urban environment, it is possible to speak of an adaptive (self-adjusting / self-organising) system that changes the algorithm of its functioning and, possibly, its structure with the aim of achieving an optimal state under changing external conditions. Adaptive systems can include: living (man, family, organisation), mechanical (control and management), computer (robots, artificial neural network) ones.

In spite of the fact that this terminology, first of all, relates to the technical sphere, we consider it possible to extrapolate it to living self-organising systems. By a system we mean a set of interrelated actors working together to achieve a common goal. Moreover, adaptation takes place due to the self-organisation of the system, which has the property of changing for the purpose of self-improvement (for example, in order to improve or preserve the sustainability of the parameters characterising this system) ${ }^{1}$.

1 GOST R 43.0.4-2009 Informacionnoe obespechenie tehniki i operatorskoj dejatel'nosti. Informacija $\mathrm{v}$ tehnicheskoj dejatel'nosti. Obshhie polozhenija $=$ GOST $\mathrm{R}$ 43.0.4-2009 Informational ensuring of equipment and operational activity. Information in the technical activity. General principles. Available from: http://docs.cntd.ru/document/1200079261 (In Russ.)

Образование и наука. Том 21, № 1. 2019/The Education and Science Journal. Vol. 21, № 1. 2019 
As the German sociologist Niklas Luhmann noted, social systems selforganise in two aspects. Firstly, they organise their own boundaries, distinguishing both what constitutes the system and what relates to the external environment. Secondly, within their boundaries they produce their own structures. The environment constantly presents new requirements to the system and the system is reproduced by self-updating taking into account these requirements [4].

The example of a self-organising system may be the community of people, including academic migrants' ones, with their mutual support, problem solving and adaptation to the new urban environment.

The theory of self-organising systems originates in the works by K. Marx, M. Weber, T. Parsons, connected with the research of the system equilibrium. However, in the last 30 years under the global crisis of all systems, the experts' attention has been focused on the lack of equilibrium and the uncertainty of their behavior. This thesis is consistent with the theory of the Nobel Prize winner I. Prigogine. Consequently, any society is referred to complex, non-linear, dynamic self-organising systems, consisting of a multitude of interacting actors and individual communities.

For specialists in the field of sociology I. Prigogine's works are more than relevant now. The modern globalising world with dangers threatening its very existence is not at all a sustainable system. Therefore, it is vitally necessary to switch from studying the ways of the equilibrium of social systems and their predetermined behavior (K. Marx, M. Weber, T. Parsons) to the study of the indeterminacy of their behavior. Every society constantly interacts (collides) with other societies-systems. At certain stages, these external influences lead a society into a state of disequilibrium where the sustainability of the society falls due to internal causes [4].

Nonlinear systems, which include complex self-organising social systems, have unsustainable states. For them, the minimum entropy theorem (in sociology as a measure of statistical uncertainty) does not work; on the contrary, the non-equilibrium processes occurring in such systems lead to an increase in entropy, i.e. sustainability of the state is not automatically ensured. The possibility of their instability is the reason for the complex behavior of such systems.

In the system, there are transitions between different types of the order. Not all of these transitions have the same sustainability (in terms of striving for maximum sustainability). However, among them there is such a transition, which corresponds to the principle of maximum sustainability. This transition can be called the development of the system.... Restoration of sustainability oc- 
curs through the people's choice of one of the possible ways of development. The choice of the direction of development is realised as a resultant of all social forces participating in the interaction for the transformation of a society. Here the key place is occupied by the principles of the ideals selection, on the basis of which a new society as a transformed social system with new channels of socialisation and a new set of socio-cultural values is formed [4].

In addition, the activities of any organisation often focus on interpersonal interactions. The most significant characteristic of the global space is its interaction with representatives of different cultures. It also determines the importance of intercultural interpersonal interactions.

However, role models of behavior among different peoples belonging to different civilisations have both common features (due to the commonness of functional expediency) and differences due to the originality of cultures which lead to the widespread dissemination of research on interethnic communication $[5$, p. 35-43].

One of the Russian experts O. D. Kutsenko, relying on the ideas of the theory of Synergetics, formulates the following fundamental characteristics of transforming (self-organising) societies [4]:

1. In a transforming society, the state of decomposition prevails, i. e. its logic develops in accordance with its independent subsystems.

2. In a transforming society there can be many options for structuring social relations, mechanisms for the formation and reproduction of these relations.

3. In a transforming society, a dominant role is played not so much by purposeful processes and cause-and-effect relationships, as by nonlinear processes of self-organisation. Self-organisation means the process of the formation of various structures of a society, which arises spontaneously and is manifested by intermittent transitions from a disorder to a new order, and vice versa. In the emerging process of self-organisation, the decisive role is played not by a chain of causes and effects but by the chances that are revealed as a result of responses to internal and external disturbances.

4. The content of emerging social forms is the result of cooperative actions of people and institutions trying to realise their interests by adapting or overcoming structural barriers in accordance with their own ideas. Thus, the choice of people in the situation of everyday life is crucial in the process of change and public stability. If the orientations and rules of interactions within the existing choices networks differ significantly from those declared by institutional forms, then the inversion of institutional forms under the influence of existing networks of relations may occur. Thus, history appears as the result of the actions of social actors, and not as the consequence of a certain way. 
In other words, a changing society is a disequilibrium social system where targeted changes must be undertaken to restore homeostasis (a sustainable state).

At the micro level the structural elements of self-organising systems are the individual positions of its participants, which must be taken into account while working with them. In this regard, it is possible to talk about the academic community in a university environment that requires its participants' compliance with certain norms as a means of social regulation of behavior. Thus, social behavior is ensured by the development and implementation of norms predetermined by value priorities and standards adopted in a given society and culture, through which the self-regulation of behavioral norms takes place in a certain cultural environment.

One of the strategic guidelines for the sustainable development of the urban environment is, in our view, the activities of a person who becomes not only an active creator of effective solutions, including applied ones, but also an initiative moderniser of existing models of creating a society in order to improve the quality of their life. In place of reactive competencies come proactive, i.e. the ability to anticipate problems becomes more important than the ability to solve them. A person must constantly strive for self-improvement and broadening 'the horizons of awareness' [6, p. 100-101]. H. Spencer, asking the question: "What kind of knowledge is the most valuable and important?", notes, "The knowledge that will help young people cope with problems and prepare them for solving problems usually arising in a democratic society" [7].

However, in order to solve numerous problems in the conditions of an unsustainable state of social systems (growth of entropy) self-organising systems often lack information. Consequently, following the provisions of the theory of information, we understand entropy as a measure of the lack of information in the system and the degree of the system organisation. This situation is consonant with the knowledge economy, where knowledge and human capital are the main factors of development.

The role of education, in particular the higher professional, in the light of this need seems to us paramount. It should be noted that at the moment there are significant changes in the system of higher education. For example, Gordon Dryden and Janette Vos suggest replacing the current system of mass education with 'self-directed' learning, based on the principles of cognitive science and on the natural ambition for learning that is inherited in every person from birth [8, p. 105-140]. Fermin Torrano Montalvo and Maria Car- 
men Gonzales Torres address in their research on 'self-regulated' learning, which has become a current focus of educational practice [9, p. 2].

In general, the potential of the human personality is unlimited and its manifestations are diverse. As D. V. Bugrov, Director of the Institute of the Humanities and Arts of the Ural Federal University, notes: "The further the world goes deeper into the technological progress, the greater role is played by information technologies, nanotechnologies and space technologies, the more important will be human factors... Every person is a peculiar individuality but not an appendage of the technological progress... It is always necessary to remain a human and support interhuman, living communication, even if in the world technologies, gadgets and the global Internet are dominated. People, according to D. V. Bugrov, should be unique and emphasise their individualities, so they will be interesting for others. As the interest in technology and engineering increases, people's interest in spiritual values increases as well. They are people but not special computer programs, who control technologies. They are the ones who promote culture. The economy is also created by people" [10].

Thus, Y. F. Fukuyama reaffirms: "The failure to understand that the basics of economic behavior lie in the field of consciousness and culture leads to a widespread misconception that in a society material causes are attributed to phenomena that by their nature are essentially of the spirit realm" [11].

Experts who can cope with many complex levels in the process of globalisation and act effectively in the conditions of diverse cultural trends must be completely different. They, indeed, should be able to effectively function in the intercultural context, i.e. they need competences that allow them to operate in a competitive environment and multicultural world.

However, there are several problems associated with adaptation of academic migrants, as they are considered 'vulnerable' when learning to adjust in the new intercultural environment [12, p. 823].

\section{Materials and Methods}

To determine specific problems of the adaptation of academic migration in the urboecological environment, we have conducted a research with foreign first year students of full-time study. The sample consists of 40 students from 20 countries of the near and far abroad, enrolled at the Ural Federal University (UrFU) in 2015. The results of the research have shown that 37 out of 40 students have problems in intercultural communication due to insufficient knowledge of a foreign language or unwillingness to join the new cultural environment, to learn and adapt to new conditions. Students have not adapted 
to the new conditions of life and their adaptation is difficult. Only 3 students from the general sample identify themselves with the students' environment and strive to fully adapt to it, to study completely immersed in the language environment, they have a positive motivation for learning activities [13].

Hence, the important moment of adaptation and assimilation of the corresponding behavioral patterns is the need to train to follow them in a particular social system.

At present, some measures are being taken to expand the availability of technological means. In many Russian institutions of higher education special techniques are being developed and specialised training materials are being created and implemented (interactive teaching aids, training videos, audio programs, computer training programs, etc.).

While analysing the functional features of the humanitarisation of technical education, as well as the pedagogical conditions, which are necessary to achieve the goals of humanitarisation, we have found that the competitiveness of modern specialists depends not only on mastering the future professional skills, but also on their humanitarian culture, creative thinking, and upbringing.

Besides, it should be borne in mind that our time is the era of a self-organising environment. The young generation is accustomed to 'adjust' the surrounding world, making it more convenient for them. Students should be able to 'adjust' the learning process to some extent, so that each of them can get knowledge in the most convenient way. This condition correlates with the theory of self-organising systems [14, p. 114].

It is also worth noting that the perception of different types of information by the younger generation is based on a new cognitive style - clip-art thinking. In the Russian science, the term 'clip-art thinking' was first used by the philosopher F. I. Girenok in 1995. Girenok believes that conceptual thinking does not play an important role in the modern world and is replaced by a clip-art one [15].

The term 'clip-art thinking' (English: clip - 'a text fragment', 'newspaper clippings', 'an excerpt from a video or film') means a person's peculiarity of perceiving the world through short bright images and TV news or video clips. Thus, this type of thinking becomes a mechanism of adaptation to the development of information technologies in the 21 st century, when the consciousness of a modern person naturally adapts (self-organises) to respond to the huge amount of information that comes from various sources.

Thus, it can be concluded that in the framework of higher professional education there is a need for the combination of personally-oriented learning 
aimed at the development of socially significant qualities (with the leading role of the humanitarian subjects) and modern information and communication technologies, without which the life in the modern world seems impossible. In this case, the lecturer's role in creating conditions contributing to personal development, based on the recognition of one's own uniqueness and exclusivity, understanding of the need for self-improvement, as well as the desire for active participation in the life of society, is especially emphasised.

In our opinion, the criteria for assessing the professional competence of a lecturer is the effectiveness of organising a favorable space for joint activities where the intercultural, social, educational and personal factors are unified by creating a psychologically comfortable educational environment that creates conditions for the productive mastery of knowledge, as well as the effectiveness of the formation of certain knowledge and skills through the disclosure of students' individual features.

Therefore, in order to maximise the use of the thinking skills of the modern young generation, special attention should be paid to encouraging and stimulating the creation and implementation of educational materials in the educational space, which are based on all the advantages of information and communication technologies. And in our opinion, in the creation of such educational resources both lecturers and students can participate. Thus, during the entire period of study self-organisation of the students' audience takes place in order to create their own content and to assimilate not only special but also socially significant competencies necessary for adaptation in a new intercultural environment.

As for foreign language classes, we can say that they are the richest platform for teaching not only the language itself, but also intercultural parameters, in particular, the development of intercultural communicative tolerance based on modern telecommunication technologies. Thus, self-organisation of the learning environment takes into account the type of thinking and a certain socio-cultural environment corresponding to the goal of adapting both academic migrants and the natives.

Speaking about multicultural symbiosis in the language (as a part of culture), we should consider the language policy that the titular nation is carrying out with respect to the small one, as well as the correct methods of teaching foreign languages, so that training becomes really necessary and beneficial for those who learn them.... Language policy should be aimed at understanding cultural differences and incorporate the values of learners. Thus, T. Mebuke offers a symbiosis of cultures, which preserves their rich variety making our world diverse and interesting [1]. 
To determine the appropriate teaching methodology, we have conducted a psychological and pedagogical research. In total, experimental research involved 132 students, who formed 2 groups: experimental (76 students) and control (56 students).

Based on the results of the theoretical research, we have drawn up a program of experimental study aimed at developing intercultural communicative tolerance in students of telecommunication specialties in foreign language classes [16, p. 114-118].

At the diagnostic stage of the research, the initial level of the students' intercultural communicative tolerance was determined using such methods as observation, group discussions, exchange of opinions, and the V. Boyko's psychological questionnaire for the diagnosis of general communicative tolerance $[17$, p. 60-65].

\section{Results and Discussion}

The results of qualitative and quantitative assessment at the diagnostic stage have revealed the levels of intercultural communicative tolerance (cognitive, evaluative, motivational-evaluative, reflexive and activity-oriented), and shown that these levels are insufficiently formed and there is a need for their development.

As part of the activities aimed at developing and improving socially important personal qualities, we have developed and implemented a methodology for developing students' intercultural communicative tolerance using such modern information and communication technologies as podcasts within the framework of the "Foreign Language" discipline.

The results of the qualitative and quantitative assessment at the final stage have made it possible to conclude that the cognitive, evaluative, motivational-evaluative, reflexive and activity-oriented components of intercultural communicative tolerance in the experimental group are sufficient. In general, the level of the students' intercultural communicative tolerance in the experimental group (EG) is assessed as high compared to the students of the control group (CG) (table 1, 2).

The developed training tutorial "Five Lessons for Developing Tolerance" has been approved and reviewed by higher educational institutions in Armenia, Brazil, Hungary, Russia, Slovakia, USA and Croatia as a teaching and methodical tutorial aimed at developing students' intercultural communicative tolerance in foreign (English) language classes [18]. A. S. Bocharnikova and S. A. Eremina specify the practical significance of the tutorial for intercultural communication [19, p. 123]. 
Table 1

Components level of the students' intercultural communicative tolerance in the experimental and control groups at the diagnostic stage, $\%$

\begin{tabular}{|l|c|c|c|c|c|c|}
\hline \multirow{2}{*}{ Level } & \multicolumn{3}{|c|}{ EG } & \multicolumn{3}{c|}{ CG } \\
\cline { 2 - 7 } & High & Medium & Low & High & Medium & Low \\
\hline Cognitive & 7.7 & 62.7 & 29.6 & 8 & 63 & 29 \\
\hline Evaluative & 6.3 & 62.7 & 31 & 6 & 60 & 34 \\
\hline $\begin{array}{l}\text { Motivational- } \\
\text { evaluative }\end{array}$ & 97 & 3 & 0 & 92 & 8 & 0 \\
\hline Reflexive & 22 & 66 & 12 & 18 & 64 & 18 \\
\hline $\begin{array}{l}\text { Activity-orien- } \\
\text { ted }\end{array}$ & 4 & 41.7 & 54.3 & 4.4 & 43.3 & 52.3 \\
\hline
\end{tabular}

Table 2

Components level of the students' intercultural communicative tolerance in the experimental and control groups at the final stage, $\%$

\begin{tabular}{|l|c|c|c|c|c|c|}
\hline \multirow{2}{*}{ Level } & \multicolumn{3}{|c|}{ EG } & \multicolumn{3}{c|}{ CG } \\
\cline { 2 - 7 } & High & Medium & Low & High & Medium & Low \\
\hline Cognitive & 90 & 10 & 0 & 7.3 & 63 & 29.7 \\
\hline Evaluative & 94.3 & 5.7 & 0 & 6.7 & 59 & 34.3 \\
\hline $\begin{array}{l}\text { Motivational- } \\
\text { evaluative }\end{array}$ & 100 & 0 & 0 & 85 & 15 & 0 \\
\hline Reflexive & 25 & 49 & 26 & 16 & 69 & 15 \\
\hline $\begin{array}{l}\text { Activity-orien- } \\
\text { ted }\end{array}$ & 83.7 & 13.3 & 3 & 5 & 42.7 & 52.3 \\
\hline
\end{tabular}

In addition, the tutorial is positively evaluated by the Academic Council of the Institute of Social and Political Sciences of the UrFU for specific scientific and applied research results. The authors of this educational tutorial have received recognition and encouragement from the Academic Council for the significant personal contribution to the development of science and education at the university.

Thus, we have proved that humanitarian disciplines, in particular foreign languages, can be a sufficient platform for the development of socially significant personal qualities and adaptation in a new intercultural environment.

Positive results of the experienced teaching of a foreign (English) language, based on a combination of communication and information technologies, have proved the effectiveness of the methodology developed and tested by us and allowed us to identify methodological opportunities for the development of intercultural communicative tolerance, which include:

1. Creation and maintenance of a favorable psychological space during the productive joint activities and solving problems in order to teach the ba- 
sics of respectful, benevolent, equal, tolerant communication and, as a result, the development of communicative, sociocultural and sociolinguistic skills in students and academic migrants;

2. In-depth training in a foreign language by involving students in the language of another culture in order to develop their linguistic and cultural skills and, as a result, to obtain competitive professionals who are able and ready to use a foreign language in daily and professional activities on a level sufficient for the implementation of intercultural communication;

3. Application of a communicative-oriented approach to training in order to obtain competitive specialists who are ready to carry out interpersonal and intercultural communications and who possess not only the necessary professional but also socially significant skills that facilitate the adjustment process and adaptation to difficult cross-cultural conditions [20, p. 272].

Thus, using modern teaching technologies and creating psychologically comfortable conditions of communication in a foreign language, it is possible to achieve the maximally possible development of trainees' individual characteristics and various potentials (intellectual, creative, professional, communicative). Moreover, the use of modern information and communication technologies connecting with the self-organisation of the surrounding space, contributes to an increase in motivation for studying; students feel comfortable, become more receptive to the teacher's words and actions.

The teacher, in turn, can draw the audience as close as possible, provoking complete trust and as a result to achieve the set goal, i.e. changing the thinking and shaping the humanistic, cultural, value, behavioral benchmarks necessary for interpersonal and intercultural interaction in the conditions of modern society development and orientation to improvement of the life quality.

The consequence is personal freedom of the individual, possessing a sense of dignity and respect for people, able to build relationships in the process of interpersonal communication, including with participants of different nationalities, based on tolerance and cooperation; a person who is able to make independent decisions and be responsible for their consequences, who can act without external forcing, who respects the choice and decisions of other people, who are considered with their positions, views and assessments.

Promising areas for further research can be: the use of the developed tutorial "Five Lessons for Developing Tolerance" as an additional block of assignments and exercises in the 'Foreign Language' discipline in order to further developing students' intercultural communicative tolerance at all levels and areas of study; the development and implementation of a program for ret- 
raining and mastering the skills of the teaching staff, also focused on the development of intercultural communicative tolerance.

\section{Conclusion}

Having considered the theoretical points concerning self-organising systems operating under new environmental conditions, the following conclusions can be drawn:

1. In the description of social systems, ecological terminology dealing with the anthropogenic factor in the conditions of the urboecological environment is increasingly used. This fact leads to the need for deeper research of the human factor, including in the field of academic migration flows.

2. Modern academic migration is a self-organising system that forms ethnic communities in any sphere including academic environment that support each other.

3. One of the Urboecology problems is the adaptation of both incoming academic migrants and the natives.

4. Practical activities should be aimed at optimising interactions between the actors involved, which require studying the human factor constantly moving from one urboecological niche to another and disrupting the equilibrium of social systems.

5. To solve problems in the conditions of disequilibrium of social systems, they lack information. In this regard, the role of education is paramount. In particular, among the disciplines of the humanities cycle one can single out the teaching foreign languages as a basis for the development of socially significant qualities, taking into account the psychological characteristics of the trainees.

6. On the basis of experimental research, we have developed and implemented a methodology for developing intercultural communicative tolerance, as one of the socially significant qualities of a personality, in foreign language classes and obtained significant positive results. Moreover, in the creation of the program the students themselves have been involved, having the opportunity to 'self-organise' the academic environment, which corresponds to the theory of self-organising systems.

\section{References}

1. Mebuke T. Multicultural problems in language teaching. The Art-Sanat Journal. 2016: 609-614.

2. Krasinets E. S. Mezhdunarodnaja migracija naselenija v Rossii v uslovijah perehoda $\mathrm{k}$ rynku = International migration of Russian population in market transition period. Moscow: Science; 1997. 191 p. (In Russ.)

Образование и наука. Том 21, № 1. 2019/The Education and Science Journal. Vol. 21, № 1. 2019 
3. Aumair S. Migration needs fair responsibility sharing based on EU-wide solidarity. In: 3rd Migration Forum (European Commission (EC) and the European Economic and Social Committee (EESC)) [Internet]; 2017 March 2-3; Brussels. Brussels; 2017 [cited 2018 Oct 15]. Available from: https://www.eesc.europa.eu/lt/node/46580

4. Shkaratan O. I. Obshhestvo kak slozhnaja samoorganizujushhajasja sistema = Society as complex self-organising system. Sociologija neravenstva. Teorija i real'nost' = Sociology of inequity. Theory and reality [Internet]. Moscow: Graduate School of Economics; 2012 [cited 2017 May 6]. 526 p. Available from: http://texts.news/struktura-stratifikatsiya-sotsialnaya/obschestvo-kak-slojnaya-29628.html (In Russ.)

5. Shkaratan O. I. Sociologija neravenstva. Teorija i real'nost' = Sociology of inequity. Theory and reality. Moscow: Graduate School of Economics; 2012. 526 p. (In Russ.)

6. Kutsenko O. D. Society and political intervention: From functional roles to the inversion of subject and object. Sociologicheskij zhurnal = Sociological Journal. 2009; 2: 97-103. (In Russ.)

7. Spencer H. Education: Intellectual, moral, and physical [Internet]. New York: A. L. Burt Company, Publishers; 1981 [cited 2018 July 28]. 309 p. Available from: https://mises.org/library/education-intellectual-moral-and-physical

8. Dryden G., Vos J. The learning revolution. Moscow: Parvine; 2003. $666 \mathrm{p}$

9. Fermin Torrano Montalvo, Maria Carmen Gonzalez Torres. Self-regulated learning: Current and future directions. Electronic Journal of Research in Educational Psychology. 2004; 2 (1): 1-34.

10. Bugrov D. My uchim stavit' vysokie celi i dostigat' ih = We teach to set goals and achieve them [Internet]. Ural Federal University: website. Available from: https://urfu.ru/ru/applicant/hr/ (In Russ.)

11. Kapitsa S. Paradoksy rosta: zakony razvitija chelovechestva = Paradoxes of growth: Laws of global development of humanity. Moscow: Publishing House Al'pina non-fikshn; 2012. 204 p. (In Russ.)

12. Wang Y., Li T., Noltemeyer A., et al. Cross-cultural adaptation of international college students in the United States. Journal of International Students. 2018; 8 (2): 821-842.

13. Kuprina T., Sergeeva L. Impact of anthropogenic factor on urboecological space development. In: International conference on sustainable cities (ICSC 2016) [Internet]; 2016 May 19; Ekaterinburg, Russia. 2016 [cited November 17 2018]. Available from: https://www.e3s-conferences.org/articles/e3sconf/abs/ 2016/01/e3sconf_icsc2016_01005/e3sconf_icsc2016_01005.html

14. Koats D. Generational learning styles. Moscow: MAPDO; 2011. $121 \mathrm{p}$.

15. Girenok F. I. Anthropological configurations of philosophy. Filosofija nauki $=$ Philosophy of Science. 2002; 8 (1): 408-426. (In Russ.)

16. Beketova A. P., Kuprina T. V., Petrikova A. Development of students' intercultural communicative tolerance in the university multilingual educational environment. Obrazovanie i nauka = The Education and Science Journal. 2018; 20 (2): 108-124.

Образование и наука. Том 21, № 1. 2019/The Education and Science Journal. Vol. 21, № 1. 2019 
17. Soldatova G. U., Shajgerova L. A. Psihodiagnostika tolerantnosti lichnosti $=$ Psychodiagnostics of personality tolerance. Moscow: Publishing House Smysl; 2008. 172 p. (In Russ.)

18. Beketova A. P., Kuprina T. V. Five lessons for developing tolerance. Ekaterinburg: UrFU; 2016. 168 p.

19. Bocharnikova A. S., Eremina A. S. Five lessons for developing tolerance. Politicheskaja lingvistika = Political Linguistics. 2017; 4 (64): 120-124. (In Russ.)

20. Mesidor J. K., Sly K. F. Factors that contribute to the adjustment of international students. Journal of International Students. 2016; 6 (1): 262-282.

\section{Список использованных источников}

1. Mebuke T. Multicultural problems in language teaching // The Art-Sanat Journal. 2016. Istanbul: Istanbul University. P. 609-614.

2. Красинец Е. С. Международная миграция населения в России в условиях перехода к рынку. Москва: Наука, 1997. 191 с.

3. Aumair S. Migration needs fair responsibility sharing based on EU-wide solidarity // 3rd Migration Forum (European Commission (EC) and the European Economic and Social Committee (EESC)) [Internet]. 2017. Available from: https://www.eesc.europa.eu/lt/node/46580 (дата обращения: 15.10.2018).

4. Общество как сложная самоорганизующаяся система [Эмектрон. ресурс] // Texts.news: сайт. Режим доступа: http://texts.news/struktura-stratifikatsiya-sotsialnaya/obschestvo-kak-slojnaya-29628.html (дата обращения: 06.08.2018)

5. Шкаратан О. И. Социология неравенства. Теория и реальность. Москва: Высшая школа экономики, 2012. 526 с.

6. Куценко О. Д. Общество и социологическая интервенция: от функциональных ролей к инверсии субъекта и объекта // Социологический журнал. 2009. № 2. C. 97-103.

7. Spencer H. Education: Intellectual, Moral, and Physical [Internet]. New York: A. L. Burt Company, Publishers; 1981 [cited 2018 July 28]. 309 p. Available from: https://mises.org/library/education-intellectual-moral-and-physical $666 \mathrm{p}$.

8. Dryden G., Vos J. The learning revolution. Moscow: Parvine, 2003.

9. Fermin Torrano Montalvo, Maria Carmen Gonzalez Torres. Self-Regulated Learning: Current and Future Directions // Electronic Journal of Research in Educational Psychology. 2004. № 2 (1). Р. 1-34.

10. Бугров Д. Мы учим ставить высокие цели и достигать их [Электрон. ресурс] // Уральский федеральный университет: сайт. Режим доступа: https://urfu.ru/ru/applicant/hr/ (дата обращения: 15.09.2018)

11. Капица С. Парадоксы роста: законы развития человечества. Москва: А^ьпина нон-фикшн, 2012. 204 с.

12. Wang Y., Li T., Noltemeyer A., Wang A., Zhang J., Shaw K. Cross-cultural adaptation of international college students in the United States / J Journal of international students. 2018. Vol. 8, Issue 2. P. 821-842. 
13. Kuprina T., Sergeeva L. Impact of Anthropogenic Factor on Urboecological Space Development // International conference on sustainable cities (ICSC 2016) [Internet]. 2016. Vol. 6. Available from: https://www.e3s-conferences.org/articles/e3sconf/abs/2016/01/e3sconf_icsc2016_01005/e3sconf_icsc2016_ 01005.html

14. Koats D. Generational learning styles. Moscow: MAPDO, 2011. $121 \mathrm{p}$.

15. Гиренок Ф. И. Anthropological configurations of philosophy // Фимософия науки. 2002. Т. 8, № 1. С. 408-426.

16. Beketova A. P., Kuprina T. V., Petrikova A. Development of students' intercultural communicative tolerance in the university multilingual educational environment // Образование и наука. 2018. Т. 20, № 2. С. 108-124. DOI: 10.17853/1994-5639-2018-2-108-124

17. Солдатова Г. У., Шайгерова $\Lambda$. А. Психодиагностика толерантности мичности. Москва: Смысл, 2008. С. 60-65.

18. Бекетова А. П., Куприна Т. В. Five lessons for developing tolerance $=$ Пять уроков развития толерантности: практикум. Екатеринбург: УрФУ, 2016. 168 с.

19. Бочарникова А. С., Еремина А. С. Five lessons for developing toleranсе. Пять уроков развития толерантности // Политическая мингвистика. 2017. № 4 (64). C. 120-124.

20. Mesidor J. K., Sly K. F. Factors that Contribute to the Adjustment of International Students // Journal of international students. 2016. Vol. 6, Issue 1. P. 262-282.

информаиия об авторах:

Куприна Тамара ВАадимировна - кандидат педагогических наук, доцент кафедры иностранных языков и перевода Уральского федерального университета им. первого Президента России Б. Н. Ельцина, Екатеринбург, Россия. E-mail: tvkuprina@mail.ru

Бекетова Анна Павцовна - кандидат педагогических наук, старший преподаватель кафедры иностранных языков и перевода Уральского федерального университета им. первого Президента России Б. Н. ЕАьцина, Екатеринбург, Россия. E-mail: annishuara@ya.ru

Минасян Светмана Михаймовна - PhD, доцент кафедры теории и истории педагогики Армянского государственного педагогического университета им. Х. Абовяна, Ереван, Армения. E-mail: s.minasyanpmesi@gmail.com

Вклад соавторов. Все авторы приняли равнозначное участие в подготовке статьи и изможенном в ней исследовании.

Статья поступима в редакцию 05.10.2018; принята в печать 16.01.2019. Авторы прочитали и одобрили окончательный вариант рукописи.

Information about the authors:

Tamara V. Kuprina - Candidate of Pedagogical Sciences, Associate Professor, Department of Foreign Languages and Translation, Ural Federal University 
named after the first President of Russia B. N. Yeltsin, Ekaterinburg, Russia. E-mail: tvkuprina@mail.ru

Anna P. Beketova - Candidate of Pedagogical Sciences, Senior Lecturer, Department of Foreign Languages and Translation, Ural Federal University named after the first President of Russia B. N. Yeltsin, Ekaterinburg, Russia. E-mail: annishuara@ya.ru

Svetlana M. Minasyan - PhD, Associate Professor, Department of History and Theory of Pedagogy, Armenian State Pedagogical University after Kh. Abovyan, Yerevan, Armenia. E-mail: s.minasyanpmesi@gmail.com

Contribution of the authors. All authors have contributed equally to writing this manuscript and to the research conducted.

Received 05.10.2018; accepted for publication 16.01.2019.

The authors have read and approved the final manuscript. 